\title{
Public Finance Review
}

http://pfr.sagepub.com

\section{Estimating Differential Responses to Local Fiscal Conditions: A Mixture Model Analysis \\ David L. Sjoquist, Mary Beth Walker and Sally Wallace \\ Public Finance Review 2005; 33; 36 \\ DOI: $10.1177 / 1091142104270656$}

The online version of this article can be found at: http://pfr.sagepub.com/cgi/content/abstract/33/1/36

\author{
Published by: \\ (5)SAGE Publications \\ http://www.sagepublications.com
}

Additional services and information for Public Finance Review can be found at:

Email Alerts: http://pfr.sagepub.com/cgi/alerts

Subscriptions: http://pfr.sagepub.com/subscriptions

Reprints: http://www.sagepub.com/journalsReprints.nav

Permissions: http://www.sagepub.com/journalsPermissions.nav

Citations (this article cites 22 articles hosted on the

SAGE Journals Online and HighWire Press platforms):

http://pfr.sagepub.com/cgi/content/refs/33/1/36 


\title{
ESTIMATING DIFFERENTIAL RESPONSES TO LOCAL FISCAL CONDITIONS: A MIXTURE MODEL ANALYSIS
}

\author{
DAVID L. SJOQUIST \\ MARY BETH WALKER \\ SALLY WALLACE \\ Georgia State University
}

\begin{abstract}
Alternative hypotheses exist regarding the impact of local sales and income taxes on local governments' taxing and spending decisions. One hypothesis is that local governments use sales and income taxes to pay for spending increases and leave property tax collections unchanged, while an equally plausible alternative is that local governments use sales and income taxes to reduce property taxes. Traditional models that restrict the impact of these local taxes to be the same across all local governments are not able to capture both types of behavior. The methodological difficulty lies in allowing for differences in behavior with no a priori information on which cities belong in which category. In this article, the authors use panel data to estimate a mixture model of spending and property tax response to the existence of local taxes. These empirical results provide evidence to support both hypotheses. These differences are both substantive and statistically significant.
\end{abstract}

Keywords: local sales tax; local income tax; tax structure; mixture model

\section{INTRODUCTION}

Local sales and income taxes have become increasingly important to local governments. In 1963, only twelve states had authorized local governments to impose a sales tax, while currently local sales taxes are imposed in thirty-four states. ${ }^{1}$ Since the early 1970s, the number of local governments with sales taxes grew from 2,817 to 6,579, as of 1994 (Advisory Commission on Intergovernmental Relations [ACIR] 1995b). The local income tax has not been utilized as widely; in 1997, there were only eleven states in which local governments imposed the

PUBLIC FINANCE REVIEW, Vol. 33 No. 1, January 2005 36-61 DOI: $10.1177 / 1091142104270656$

(C) 2005 Sage Publications

36 
local income tax. ${ }^{2}$ However, in the mid-Atlantic and Midwest regions that have adopted it, its use has grown over the past three decades. For example, the states of Alabama, Indiana, Iowa, Kentucky, and Ohio saw significant increases in the number of local jurisdictions using the income tax between 1970 and 1994.

Substantial public revenues are associated with these taxes. Revenues from local sales taxes represents about 16 percent of cities' revenues. For larger cities, this percentage drops to between 12 and 13 percent. Local income taxes are more important to large cities; in cities with more than a million in population, revenues from local income taxes represent about 25 percent of total revenues.

What happens to local revenue and expenditures when local governments adopt a local sales or income tax? How the revenue from these taxes will be used is a policy issue faced by state governments when deciding whether to allow local governments to use new taxes. Interest in this issue is evident in the popular press, and a review of numerous news stories suggests that there is a debate surrounding the use of local sales and income taxes. Based on our search of the debate, on one side of the issue is an argument for using local income taxes as a substitute for property taxes (Buffalo News 1993; Intelligencer Journal 1998; Times Leader 2003), while the other side posits the adoption in terms of general budgetary expansion (Pittsburgh Post-Gazette 1994; New York Times 1997). A similar debate exists for the sales tax, with some politicians and citizens supporting the use of the sales tax to increase expenditures (St. Petersburg Times 1987; Omaha WorldHerald 1997; St. Louis Post-Dispatch 1997), while others support the substitution of sales taxes for property taxes (Houston Chronicle 1994; Atlanta Journal and Constitution 1995). Overall, it does seems that there is more popular support for a local sales tax to support expenditures versus its use to relieve property taxes.

Our research investigates whether local sales and income taxes are used to fund additional expenditures or to reduce property taxes and is related to the literature that explores the effect of tax structure on the level of expenditures. Perhaps not surprisingly, the existing (scarce) evidence on the question of the effect of the tax structure on the level of expenditures and property taxes is mixed. Oates (1988), Hettich 
and Winer (1999), and Merrifield (2000) provided reviews of this literature. Wagner (1976) and Breeden and Hunter (1985) found that cities with diversified tax structures have higher expenditures than cities with less diverse tax structures, while Inman (1979) did not. Clotfelter (1976), Baker (1983), and Suyderhoud (1994) focused on state-level expenditures and obtained results that are consistent with Wagner's, while Ladd and Weist (1987) did not. ${ }^{3}$ These papers are related to our research since adopting a local sales or income tax increases the diversity of the tax structure. The findings of some studies are consistent with the hypothesis that a new tax will lead to increased expenditures, while other studies are consistent with the hypothesis that a new tax leads to lower property taxes.

More closely related are studies that consider whether the adoption of a new tax results in higher total tax revenue (and so increased expenditures) or in lower property taxes. In an early piece, Deran (1968) compared cities with and without local income taxes and concluded that cities with an income tax have lower per capita property taxes. Anderson (1995) suggested that some cities may adopt a local tax to finance higher levels of expenditures, but Stockfisch (1985) found no effect on expenditures as a result of the adoption of VATs in Europe. To the extent that revenue from a new tax is treated the same as additional revenue from an existing source generated from economic growth, we note that Oates (1975) and Craig and Heins (1980) found a positive relationship between income elasticity of the tax structure and expenditures, while the findings of DiLorenzo (1982) and Feenberg and Rosen (1987) did not lend support to the view that expenditures increase as a result of automatic revenue increases.

Based on the newspaper stories and the literature, it is difficult to conclude whether the adoption of a local sales or income tax will result in increased expenditures or reduced property taxes. The basic approach in empirical models of this question, and of the fiscal behavior of local governments in general, is to measure a unique response to policy variables while controlling for the effects of other factors that shift the relationship. But the adoption of a local sales or income tax might be a circumstance under which local governments respond differently to the policy environment and where control variables are un- 
likely to capture these differences. Some cities may adopt a local tax to finance higher levels of expenditures (as suggested by Anderson 1995), while other cities might hope to reduce reliance on property taxes (as suggested by ACIR 1988). In this case, an empirical model that restricts the impact of local taxes to be equivalent across citiesa typical empirical approach in this literature-cannot capture the effect of these different motives.

This poses a difficulty for the empirical modeling of the behavior of these governments if the different responses have no apparent association with observable characteristics of the cities. For example, suppose that there is some population of cities that adopt local taxes primarily to provide property tax relief while another population of cities adopt local taxes to increase expenditures. If we wish to determine the effect of the local sales or income tax on property tax revenues but our sample contains both types of cities, our measurement of the effect on property taxes will be flawed. Depending on the mix of cities in our sample, we could find no effect, an increase in expenditures, or a reduction in property taxes.

In this article, we specify and estimate a model that allows cities to choose different expenditures and property tax revenues in response to fiscal conditions, in particular the existence of local sales and income taxes. We adopt an empirical approach, a mixture model, that allows cities to sort into two different groups, each with different conditional means for expenditures and property tax revenues. Unlike traditional switching models, this sorting is not based on an arbitrary assumption about the sorting mechanism. These mixture regression results provide support for our contention that local sales and income taxes have different impacts across cities on their expenditures and property taxes. These differences are both substantive and statistically significant.

The rest of the article proceeds are follows. The next section outlines scenarios that lead to differential responses among cities to the existence of a local sales or income tax. This is followed by sections that provide an overview of the mixture model employed and our empirical model. We then discuss the results and provide a brief conclusion. 


\section{REASONS FOR EXPECTING A DIFFERENTIAL RESPONSE}

There are many possible reasons why cities could respond differently to the existence of a local sales or income tax. Although it is possible to use control variables to capture some of these differences, we are not able to control adequately for other differences. There are many potential reasons why we might expect cities to show different responses to the existence of a local sales or income tax and for which we are unable to adequately empirically capture through control variables. In this section, we describe some scenarios that illustrate some of these reasons; this is not an exhaustive analysis.

Scenario 1. Consider the following very simple framework. Assume that public outcomes are determined by the median voter. ${ }^{4}$ Let individuals determine their preferred levels of public expenditures within the context of a normal utility-maximizing framework. Let utility be a function of a private good $X$ and the per capita amount of a publicly provided private good $E$ financed through a property tax $(P T)$. (To keep this as simple as possible, we do not include housing in the utility function; this assumes that the property tax base is fixed.) Let the income constraint be given by a fixed income, $I$, a price of $X$ equal to one and a tax price for the publicly provided good, $\tau$. The individual determines her or his optimal private good and expenditure, denoted $X^{*}$ and $E^{*}$, by equating the marginal rate of substitution to the price ratio.

Now suppose that the local government adopts a sales tax (ST) that finances some but not all of the public expenditure. In other words, the property taxes still finance the marginal unit of $E$. (This would be the case if the local government had no choice over the sales tax rate, which is the common situation.) Thus, under our assumption that tax rates do not affect the property tax base, the marginal tax price does not change with the introduction of the sales tax. The sales tax changes the budget constraint as follows:

$$
I-\alpha S T=\left(1+t_{s}\right) X+\tau(E-S T),
$$

where $t_{s}$ is the sales tax rate and $\alpha$ is the share of the sales tax paid by the individual. Rewriting the budget constraint, we get 


$$
I+(\tau-\alpha) S T=\left(1+t_{s}\right) X+\tau E .
$$

The effect of adding a sales tax on the preferred $E$ depends on the price elasticity of $X$ and the value of $(\tau-\alpha)$. Assume for simplicity that the price elasticity of $X$ is -1 , so that $t_{s}$ does not effect the share of net income spent on $E$. If $\tau=\alpha$, there is no effect on $E$, and thus the sales tax results in a dollar for dollar reduction in property taxes. If $\tau$ does not equal $\alpha$, then there is an income effect on $E$. If the median voter had to approve the adoption of a sales tax, then it is expected that $\tau>\alpha$, in which case the value of $E$ preferred by the median voter will increase as a result of the adoption of the sales tax.

Several authors (see for example Wagner 1976) have suggested that a more diversified tax structure increases fiscal illusion, allowing government officials to increase expenditures beyond what might be otherwise desired. ${ }^{5}$ But there is no reason why the level of fiscal illusion will be the same for all cities. Thus, there may be differences across cities in the percentage of the sales or income tax revenue that is "used" to expand expenditure levels and to reduce property taxes. There is no empirical measure of fiscal illusion that can be used to reflect differences in the level of fiscal illusion across jurisdictions. In practice, fiscal illusion is never directly measured; rather, its existence is presumed if the empirical results are consistent with expectations (e.g., if a diversified tax structure increases expenditures). A priori, we are unable to sort cities into groups based on their differing levels of fiscal illusion.

Suppose that fiscal illusion acts through $\tau$ and $\alpha$, and in particular that the individual perceives that the tax prices are actually $\tau^{\prime}$ and $\alpha^{\prime}$. Our approach is consistent with the common approach to fiscal illusion that voters may not accuracy perceive actual taxes paid, confusing average tax prices for marginal tax prices. ${ }^{6}$ An alternative approach is offered by Turnbull (1992) and Congleton (2001), who modeled fiscal illusion as behavior under uncertainty.

Suppose that there are two individuals with the same true tax prices and income, so if there is no fiscal illusion, the two individuals would react the same upon the adoption of an $S T$; that is, if $\tau=\alpha$, both would prefer to reduce property taxes but not increase expenditures. Suppose, however, that individual 1 has no fiscal illusion but individual 2 does, and in particular, assume for person 2 that $\tau^{\prime}=\tau$ but $\alpha^{\prime}<\alpha$; that 
is, person 2 thinks her share of the sales tax is less than what it actually is. With fiscal illusion person 2 would prefer an increase in expenditures. If these two individuals are in separate jurisdictions and are the median voters in their respective jurisdictions, then the two jurisdictions will have different reactions to the adoption of the sales tax.

Scenario 2. An alternative approach to demonstrating the effects of the mix of property and sales taxes is to recognize that an individual's utility may depend directly on the level or the characteristics of the taxes; that is, the level or other features of the taxes may enter directly into the utility functions of the voters and influence their choices through these avenues. Inman (1989), for example, considered several political agents in the decision over tax structure and assumed that the city council has preferences on the net average tax rate and the mayor's utility depends on the tax burden for each taxpayer. There is also a line of research that equates the tax structure to a tax portfolio, where the various possible portfolios yield difference values for revenue growth, stability, and equity (White 1983; Misiolek and Perdue 1987; Dye and McGuire 1991; Harmon and Mallick 1994). While the papers cited analyze the feasible choice set of characteristics of the tax structures but not the actual choice, the implication is that the voters' utility is a function of the characteristics.

Suppose first that utility inversely depends on the level of property taxes and the level of sales taxes; that is, as $P T$ or $S T$ increases, utility decreases (the first derivative of utility with respect to $P T[S T]$ is negative and increasing in absolute value). There is some evidence that voters do have preferences over different types of taxes, as noted in the ACIR (1995a) studies of the "least favored tax." Opinion polls such as those conducted by ACIR suggest that the property tax is the least liked tax. Elected officials certainly act as if it is easier to increase revenue from some sources of revenue than others.

This evidence implies that individuals are not indifferent as to which tax is used to collect a given tax levy. Thus, it seems reasonable to assume that utility falls as property tax increases or as other taxes increase. Assume, then, that utility depends on $X$, per capita $E, P T$, and $S T$. (Note that since there is no marginal decision with respect to $S T$, including $S T$ in the utility function has no effect on our results except to the extent that it affects the marginal disutility from $P T$.) 
As in the first scenario, an individual, say the median voter, will select an $E$ that maximizes utility. Suppose that $S T$ is used to fund part of the public expenditure. Consider the case where $\tau=\alpha$ and ignore the effect of the sales tax on $X$. As noted above, if utility is not a direct function of the property tax, the adoption of a sales tax will have no effect on $E^{*}$. But if utility does depend on $P T, E^{*}$ will increase with the adoption of a $S T$. If initially there is no change in $E$ as a result of $S T$, then the adoption of a sales tax reduces property taxes. But with lower $P T$, the marginal (negative) utility from an increase in $P T$ will be smaller than it was at the initial value of $E$ prior to the adoption of the $S T$. Thus, the individual will desire to increase $E$ from its original level. The greater the dislike for the property tax (i.e., the more utility falls as $P T$ increases), the larger the expected increase in $E$ from the adoption of a sales tax.

Suppose that there are two types of individuals: group 1, who dislike the property tax, and group 2, who do not dislike the property tax. For given income and tax prices, we would expect that members of group 1 will prefer a smaller $E$. If we can accept the assumption that membership in the two groups is not determined by some observable characteristic such as income, then we can posit the following. Individuals with low income and no distaste for the property tax and high income individuals with a distaste may have similar $E^{*}$. If individuals sort themselves into communities based on $E^{*}$, it follows that the effect of the adoption of a sales tax will depend on the number of individuals in the community who dislike the property tax. If there are enough individuals who dislike the property tax in a community, then these individuals will drive the change in $E$ resulting from the adoption of a sales tax. In other communities, there could be many individuals who are indifferent to property taxes, so the change in $E$ resulting from a sales tax adoption will be driven by these voters. The consequence is that the effect of a sales tax will have differential effects on expenditures. Because we have assumed that group membership is not determined by observable characteristics, we will not be able to sort cities into groups based on preferences.

An alternative is to assume that utility depends on the characteristics of the tax structure. Adding a sales tax, or income tax, changes the characteristics of the tax structure. How this affects the level of expen- 
ditures can be considered in a framework similar to that above, except that the values of characteristics are functions of the mix of taxes and utility is a function of the value of each characteristic. Adding a sales tax (or income tax) changes the value of the characteristics and hence the marginal utility of property taxes. Because of differences in tastes and preferences (perhaps due to Tiebout-like sorting) and differences in how the adoption of a sales or income tax will affect the value of the characteristics (perhaps due to differences in the nature of the community), it is possible that voters in one city may respond differently to the change in tax structure than voters in another city.

But the response to the changing characteristics might be more complex than simply changing the level of expenditure. For example, the voters in one city may use more of the sales tax revenue to expand propoor expenditures in an effort to offset the presumed increased regressivity of the sales tax. On the other hand, voters in another city may decide to use more of the sales tax revenue to cut property taxes to have a "cushion" in case sales tax revenues fall.

These examples are intended to illustrate that the effect of adding a sales or income tax on the level of expenditures and property taxes may differ across cities for reasons unrelated to such observable factors as income or actual tax prices. We explore whether the data support this hypothesis. In particular, we look for evidence that some cities use the income and sales tax to expand expenditures while other cities use these taxes to lower property taxes. We do not expect to find that there is one group of cities that use the sales and income tax only to raise expenditures and another group that use the sales and income tax only to reduce property taxes, but in the following discussion it is convenient to consider the responses as distinct (i.e., using local sales and income tax revenue to either increase expenditures or reduce property taxes).

\section{MIXTURE REGRESSION MODEL}

The empirical literature to date has not found a cohesive set of results concerning the impact of the use of local sales and income taxes on expenditures or property taxes. The discussion above suggests that 
we should consider a model that allows different responses to the existence of a local sales or income tax.

Clearly, the simplest empirical approach to address these concerns would be to estimate a single ordinary least squares (OLS) equation (for either expenditures or property tax revenues) that includes interaction terms for the local sales tax variable and the local income tax variable. This approach is not feasible for us because we would have to first specify a dummy variable that would distinguish between the two groups of cities, and as stated above, the sorting does not appear to be related to observable factors. A second empirical approach would require estimating the probability that a particular city belongs to one of two groups. This would be a switching regression model in which separate equations are specified for each group of cities. Recall that to avoid selection bias, it is necessary to estimate the probability that a city belongs to a particular group, which of course means finding observable variables that are related to this probability. Estimation is typically carried out by assuming joint normality, then estimating parameters by either maximizing the joint likelihood function or through a two-step process. The switching regression approach cannot be applied in our situation because, again, we cannot find variables associated with the probability of group membership. ${ }^{7}$

A third approach, which is less demanding in terms of making assumptions on the sorting mechanism, is to set up the model as a mixture of normals, where the proportion of observations belonging to one group, or class, is estimated jointly with the conditional mean parameters. Mixture models have not been widely used in the empirical literature in economics, although the problem of a mixture of normals is a very old one in statistics. ${ }^{8}$ Day (1969) for example, presented a maximum likelihood estimator (MLE) for these models. These models are more widely used in fields such as biometrics and marketing. The heart of the issue is that the statistical investigator believes that her or his sample is drawn from two (or more) underlying populations, each with different parameters, but cannot identify which observations come from which population.

Specifically, suppose that cities belong to one of two classes: the first class uses local sales and income taxes to increase expenditures; the second class uses local sales and income taxes for other purposes. 
Let $y_{i}$ denote the real expenditures per capita for city $i$ and let the $(k \times$ 1 ) vector $x_{i}$ include the existence of a local sales and income tax, as well as other control variables. If the conditional mean of $y_{i}$ is written as $E\left(y_{i t} \mid x_{i t}\right)=x_{i t}^{\prime} \beta$ for all $I$, then it is misspecified because we are forcing the effects of $x_{i}$ to be the same for all cities. Instead, we want to estimate

$$
E\left(y_{i t} \mid x_{i t}\right)=x_{i t}^{\prime} \beta_{1}
$$

if city $i$ is in category 1 and

$$
E\left(y_{i t} \mid x_{i t}\right)=x_{i t}^{\prime} \beta_{2}
$$

if city $i$ is in category 2 . Because we do not restrict coefficients on the control variables to be constant across the two groups, it is possible that the data might support more than two groups. However, we restrict our analysis to two groups to see whether the data support our hypotheses regarding the impact of local sales and income taxes. Specification tests, such as likelihood ratio tests, to determine the appropriate number of groups are not well defined in a mixture model; see Wedel and Kamakura (1999) for details.

With the additional assumptions that the additive error, $u$, is normally distributed with $E(u \mid X)=0$ and $E\left(u^{2} \mid X\right)=\sigma^{2}$, we can specify the log-likelihood function for $n$ cities over $T$ time periods:

$$
\begin{aligned}
L\left(\beta_{1}, \beta_{2}, \sigma^{2}, \lambda\right) & =-\frac{n}{2} \ln \left(2 \pi \sigma^{2}\right) \\
& -\left[\sum_{i=1}^{n T} \lambda \frac{1}{2 \sigma^{2}}\left(y_{i}-x_{i}^{\prime} \beta_{1}\right)^{2}+(1-\lambda) \frac{1}{2 \sigma^{2}}\left(y_{i}-x_{i}^{\prime} \beta_{2}\right)^{2}\right] .
\end{aligned}
$$

The parameter $\lambda$ represents the proportion of the sample in the first category, while $(1-\lambda)$ denotes the proportion in category 2 . Identification in the mixture model requires that we assume that the error variances are the same across the two groups. Note that this assumption would not be necessary if we had more information about what factors cause the cities to sort into groups. Maximizing the log-likelihood function with respect to the unknown parameters yields estimates of the conditional mean parameters, $\beta_{1}$ and $\beta_{2}$, the common variance, $\sigma^{2}$, 
and the proportion factor, $\lambda$. Under our assumptions, and as $n \rightarrow \infty$ with $T$ fixed, the MLEs are consistent and asymptotically normally distributed. Asymptotic standard errors for the parameters are obtained from the estimated second derivative matrix. ${ }^{9}$

Note that the results allow us, ex post, to estimate the probability that observation $i$ belongs to group $k$. For example, for $k=1$,

$$
p_{i}(1)=\frac{\hat{\lambda} e_{i 1}}{\hat{\lambda} e_{i 1}+(1-\hat{\lambda}) e_{i 2}}
$$

where

$$
e_{i k}=\exp \left(-\frac{1}{2 \sigma^{2}}\left(y_{i}-x_{i}^{\prime} \beta_{k}\right)^{2}\right)
$$

and $\lambda$ is the estimated proportion of observations in the first segment.

The chief benefit of the mixture regression approach is that by estimating the probability of group membership, we do not have to identify the factors that sort cities into groups. Rather, the model allows the data to tell us the classifications. A seeming drawback to the approach is the requirement that we assume that the data generating process is normal. The assumption of normality, however, would also be required in the standard switching regression model.

\section{EMPIRICAL ANALYSIS}

We explore two specific questions: (1) whether the presence of local sales and income taxes result in lowering property taxes more in some cities than in others and (2) whether the presence of local sales and income taxes increase expenditures more in some cities than in others.

To analyze the relationship between local sales and income taxes and property taxes and expenditures, we estimate each of the equations below. Time and unit subscripts are suppressed in the following:

$$
P T=\alpha_{0 i}+\alpha_{2 i} L S T+\alpha_{3 i} L S T+\alpha_{4 i}{ }^{\prime} X_{1}+u_{i}(i=1,2)
$$




$$
E X P=\beta_{0 j}+\beta_{2 j} L S T+\beta_{3 j} L I T+\beta_{4 j}{ }^{\prime} X_{2}+u_{j}(j=1,2),
$$

where $i$ and $j$ represent the groups into which the city fall for the two equations, $P T$ is property taxes, EXP is expenditures, $L S T$ is local sales tax, LIT is local income tax, and $X$ represents a set of control variables. Note that memberships in the two groups is not necessarily the same for the two equations.

Our specific hypothesis is that cities will fall into two categories for each equation, based on the different responses to local taxes. To illustrate this with respect to the sales tax, consider the following example, assuming extreme sorting. Let $i=1$ represent cities that use $L S T$ to reduce $P T$, and let $j=1$ represent the cities that use $L S T$ to increase EXP. We expect that the estimate of $\alpha_{21}$ will be negative and significant for group one and the estimate of $\alpha_{22}$ will be insubstantial in magnitude and not statistically significantly different from zero for the other group. Likewise, we expect that $\beta_{21}$ will be positive and significant for group one, while $\beta_{22}$ will be close to zero and insignificant for the other group. Note however, that our equation specification allows all coefficients to differ between groups, so that empirical results might indicate that the sorting of cities results in different responses to factors other than just local taxes. For example, cities that strongly dislike the property tax may also have a different marginal propensity to spend on $E$.

The equations are estimated with a panel of the 101 largest cities in the United States for the period 1963 to 1990. The end of the sample period is driven by data availability. An examination of the data yields few discernible patterns regarding which cities use the local sales or income taxes. Table 1 provides descriptive statistics on all variables used in estimation.

To measure $P T$ we use real per capita property tax revenue in $\$ 1,000$ s. The average level of per capita property tax revenues, in 1982 to 1984 dollars, is $\$ 141$. EXP is also measured in real per capita terms; this variable has a mean value of $\$ 752$ over the period. There is substantial variation in these variables, both across cities and over time. Most cities tripled or doubled their expenditures during the sample period; property tax revenues typically increased by an even larger factor. Looking at average expenditures by cities, the data varied from 
TABLE 1: Descriptive Statistics

\begin{tabular}{lcccc}
\hline Variable & Mean & $\begin{array}{c}\text { Standard } \\
\text { Deviation }\end{array}$ & Minimum & Maximum \\
\hline Property tax revenues & 0.1408 & 0.1490 & 0.0066 & 1.2627 \\
Expenditures & 0.7517 & 0.5061 & 0.1481 & 4.7627 \\
Residential property & 0.667 & 0.097 & 0.075 & 0.9271 \\
$\begin{array}{l}\text { Intergovernment transfers } \\
\text { County and school }\end{array}$ & 0.239 & 0.248 & 0.0002 & 1.634 \\
$\quad$ property tax & 0.1517 & 0.2950 & 0.0000 & 7.7750 \\
Per capita income (\$) & $9,229.41$ & $1,325.26$ & 5,824 & 14,635 \\
Percentage poverty & 16.39 & 4.84 & 4.6 & 33.45 \\
Percentage older than & & & & \\
$\quad$ sixty-five & 11.52 & 3.05 & 3.30 & 30.62 \\
Property tax limitation & 0.655 & 0.475 & 0 & 1 \\
No separate school district & 0.450 & 0.498 & 0 & 1 \\
Local sales tax & 0.417 & 0.493 & 0 & 1 \\
Local income tax & 0.224 & 0.417 & 0 & 1 \\
\hline NOTE: The varibles & &
\end{tabular}

NOTE: The variables expenditures, property tax revenues, income, and the county and school property tax revenues are computed in per capita terms, $\$ 1,000$ units, in 1982 to 1984 dollars.

a low of $\$ 280$ per person to $\$ 1,710$ per person. Average per capita property taxes, by city, showed a similar spread.

LST and LIT are measured as dummy variables that equal one if the city had a sales tax or income tax in that year. ${ }^{10}$ In just more than 40 percent of the observations, a local sales tax was present; forty-nine cities never used a sales tax during the sample period, twenty cities had a sales tax throughout the entire period, and thirty-two cities adopted one during the period of observation. Fewer cities had a local income tax; fifteen cities had a local income tax during the period of observation with only eleven adoptions during the period. Revenues from city sales taxes average around 16 percent of cities' tax revenue, based on all cities. The percentage is between 12 and 13 percent for cities larger than five hundred thousand in population. City income taxes are more important to larger municipal areas, with revenues from these taxes amounting to more than 25 percent of cities' tax revenues in cities with populations more than 1 million.

We include a number of other explanatory variables in equations (8) and (9). The selection of these variables is based on previous empirical studies of expenditure determination and tax composition. The 
variables in expenditure demand equations differ across studies, but there is commonality in the types of variables included. There is less uniformity in the variables used in tax composition studies. The following variables are included in both equations. All expenditure demand studies include a measure of income and intergovernmental grants. We include real per capita income (in $\$ 1,000 \mathrm{~s}$ ), denoted $R I N C$, and real per capita intergovernmental aid (in $\$ 1,000 \mathrm{~s}$ ), denoted $R I G R$. We expect the coefficients on these variables to be positive in all the equations. Median household income is used in many studies of expenditure demand, but since it is available only in census years, we use per capita income, which is more readily available.

The demographic control variables included are the percentage of the population below the poverty level, denoted PCTPOV, which is expected to result in higher expenditures and may have a positive or negative affect on property taxes. We also include the percentage of the population over the age of sixty-five years of age, denoted OVER65, which we expect to be negatively related to property tax level and our measure of expenditures. We include a linear time trend, denoted YEAR.

Starting with Borcherding and Deacon (1972) and Bergstrom and Goodman (1973), it has been common in expenditure demand studies to use a measure of tax price (usually measured as median house value divided by property tax base), although there are many published studies that do not include it. Since median house value is available only in census years, we are unable to measure tax price this way. As a substitute, we use the residential property value as a percentage of total property value, denoted RESPROP. Higher values of RESPROP imply a higher constituent cost of expenditures and less exporting of the property tax. Thus, we expect RESPROP to be negatively related to expenditures and to the level of the property tax.

We include three additional variables in the $P T$ equation. We include PROPLIM, a dummy variable that equals one if the city had a property tax limitation in that year. ${ }^{11}$ Based on existing studies, we expect PROPLIM to be negatively correlated with property tax level. We do not include it in the expenditure equation since existing studies suggest that limitations have little effect on expenditure levels (Mullins and Joyce 1996). In some cities, education is provided directly by 
the municipal government and not a separate school district. For these cities, expenditures and property taxes are expected to be higher. Thus, we included a dummy variable, $D S$, that equals one if there is not a separate school district and zero otherwise. OPTAX is real per capita county and school district property taxes. ${ }^{12}$ This variable measures the level of competing use of the municipality's property tax base, and we expect it to be negatively correlated with $P T$.

We specify regional dummy variables for the nine census regions rather than fixed effects because, under our assumptions and with our estimation methodology, our parameter estimates would be inconsistent if fixed effects were include. ${ }^{13}$

The data were obtained from Significant Features of Fiscal Federalism (ACIR various years), City Government Finances (U.S. Census Bureau various years-c), County and City Data Book (U.S. Census Bureau various years-d), the Census of the Population (U.S. Census Bureau various years-b), and the Censuses of Government (U.S. Census Bureau various years-a). In the 1960s, population was not available in noncensus years, and so we imputed the intervening years using a constant growth rate. Other demographic variables were not available in any noncensus year, and as such we followed the same imputation procedure. To estimate income in the missing years, we assumed that the annual growth rate between reporting years was in proportion to the growth rate of per capita personal income for the United States. Data on the percentage of assessed value of property that is commercial or industrial were obtained for selected years and estimated for intervening years assuming a linear growth rate.

\section{RESULTS}

The results of the estimation are reported in Table $2 .{ }^{14}$ We find strong support for the hypothesis that there are two underlying populations represented in the sample. ${ }^{15}$ Consider first the issue of how local sales and income taxes affect property taxes and expenditures. We start with equation (1), the property tax equation. For both groups, the estimated coefficient on sales tax is negative and statistically significantly different from zero. But the coefficient for group 2 is almost 


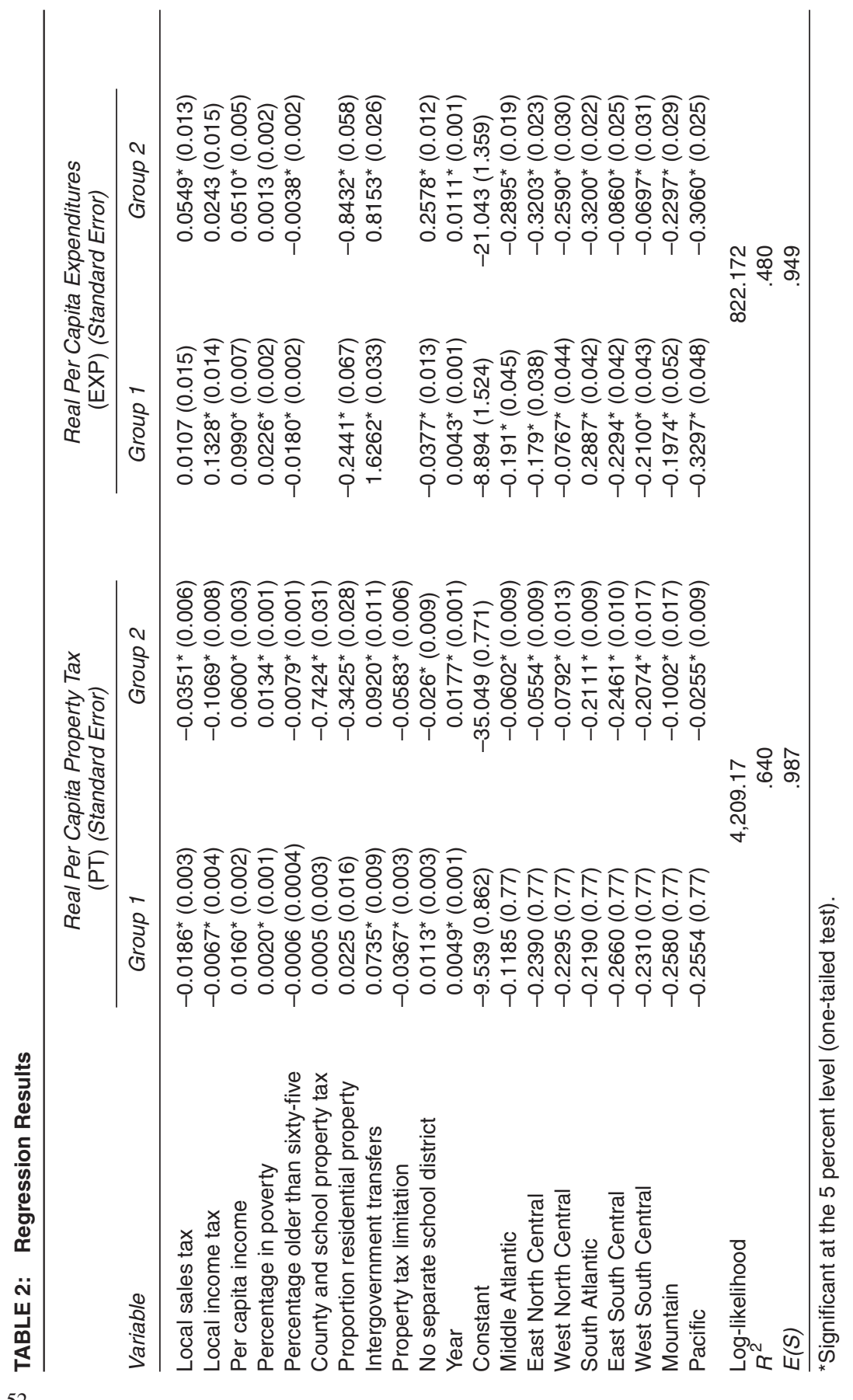


TABLE 3: Summary of Effects of Local Sales and Income Taxes

\begin{tabular}{lcc}
\hline Local Taxes Cause: & $\begin{array}{c}\text { No Reduction in } \\
\text { Property Taxes }\end{array}$ & $\begin{array}{c}\text { Reduction in } \\
\text { Property Taxes }\end{array}$ \\
\hline Increases expenditures & 42 cities & 6 cities \\
No increase in expenditures & 20 cities & 33 cities \\
\hline
\end{tabular}

NOTE: Cities sum to 101.

twice as large as for group 1; cities in group 2 with a sales tax have about $\$ 35$ per person less in property tax revenues than those group 2 cities with no sales tax. The corresponding number for group 1 cities is about $\$ 19$ less per person. For the local income tax variable, we find an even more striking difference between group 1 and group 2 cities. Group 1 cities with a local income tax have property tax revenues that are $\$ 7$ per person less relative to those group 1 cities with no income tax, but the standard error on this estimate is fairly large. However, for cities in the second group, the existence of a local income tax lowers property tax revenues by more than $\$ 100$ per person.

The results for the expenditure equations (equation [2]) also support the hypothesis of a mixture of distributions for the dependent variable. Here, group 1 cities do not appear to use the local sales tax to support higher expenditures; the coefficient on LST is small and positive, with a large standard error. However, group 1 cities appear to use local income tax revenues for increased expenditures. The estimated coefficient indicates that expenditures rise about $\$ 130$ per person when cities in this group have a local income tax. For group 2 cities, on the other hand, local sales taxes seem to support higher expenditures, with an estimated coefficient of $\$ 54.90$ per person. These cities rely on the local income tax to support higher expenditures to a much less extent; the estimated coefficient on LIT is smaller with a relatively large standard error. Table 3 summarizes these effects, showing the number of cities in each group.

The estimated models do not restrict the coefficients on any variable, not just sales and income tax variables, to be constant across groups, and the estimation results indicate that the coefficients on other variables differ substantially across the two groups. Thus, it is not just the responses to local taxes that differ across cities but the responses to most other factors. For example, in the property tax equa- 
tions, the coefficients on income, RINC, differ by a factor of more than four, while in the expenditure equations they differ by a factor of two. This suggests that the division of cities based on the property tax equation will not be the same as for the expenditure equation. In other words, cities that use the sales tax to reduce property taxes may not necessarily be the same cities that do not increase expenditures.

Nonetheless, an examination of predicted probabilities for each equation indicates that 42 cities, out of 101 total cities, are predicted to fall into group 1 for both equations. For these cities, local sales and income taxes appear to lead to small reductions in property tax revenues, whereas they seem to use the local income tax to make substantial increases in expenditures. There are 20 cities that are predicted to belong to group 2 for both equations. In this group, local taxes are used for larger reductions in property taxes and very small increases in expenditures. Thirty-three cities are predicted to fall into group 1 for property taxes and group 2 for expenditures, meaning small but statistically significant reductions in property taxes given the existence of local taxes, with small increases in expenditures. Only 6 cities are predicted to belong to group 2 for property taxes and group 1 for expenditures. The implication is that 6 cities make substantial reductions in property taxes but still have relatively larger increases in expenditures.

Figure 1 depicts predicted property tax revenues over time for the cities in each group, stratified by whether the city had a local income tax. To generate these predictions, we first computed group average values for each of the right-hand-side variables in the property tax revenue equations, except for region (which was set to one for the East North Central region and zero for the other regions.) We then computed predicted revenues for the cities in the group with a local income $\operatorname{tax}(L I T=1)$ and then for those cities in the group with $L I T=0$. The path of predicted revenues for group 1 cities shows that a local income tax makes very little difference in the level of property tax. Group 2 cities, on the other hand, show a rapid increase in property tax revenues over time, with a much bigger difference between those with and those without an income tax. If group 2 cities with an income tax had not adopted an income tax, the level of group $2(L I T=1)$ would have been substantially higher than is found in Figure 1. 


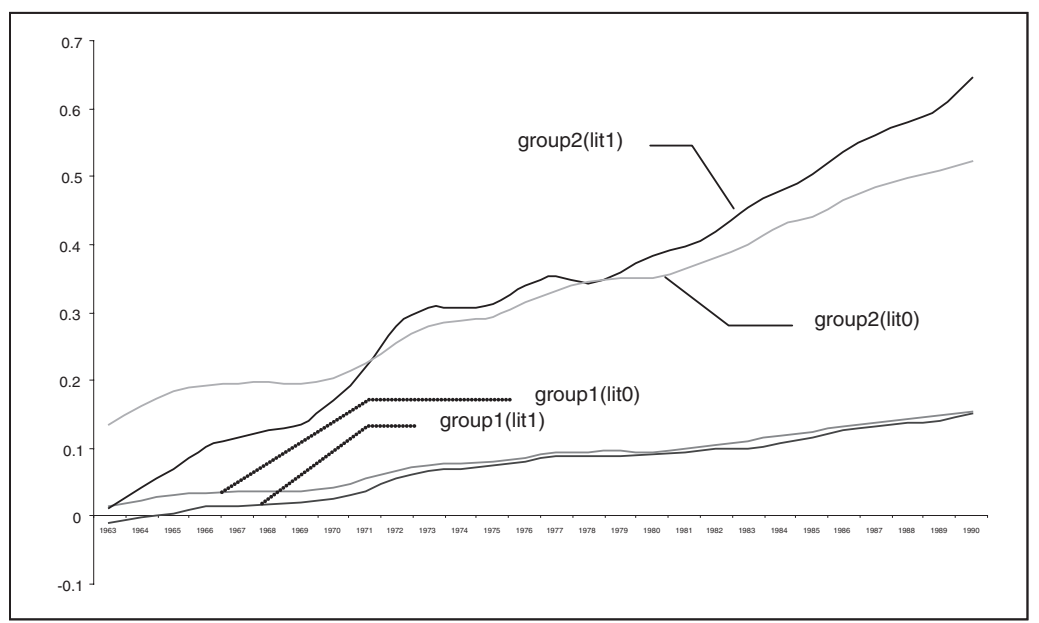

Figure 1: Prediction of Property Tax Revenue Based on Average (Year-by-Year Case)

NOTE: $Y$-axis is real property tax per capita in $\$ 1,000$ s.

A similar graph based on the expenditure equation is given in Figure 2. For group 1 cities, a local income tax provides a big boost to expenditures. The effect of a local income tax on the time path of predicted expenditures is less clear for cities in group 2; the tax provides a smaller boost to expenditures and for only part of the time period.

An entropy statistic can be computed to measure the separation of the categories or groups. This is defined in Ramaswamy et al. (1992) as

$$
E(S)=1-\sum_{i=1}^{N} \sum_{s=1}^{S}-\hat{p}_{i s} \ln \left(\hat{p}_{i s}\right) / N \ln (S)
$$

where $S$ denotes the number of groups. The $E(S)$ statistic varies between zero and one; a value of one indicates perfect separation. The $E(S)$ statistic is very close to one for both equations, implying that the separation of the sample into two groups strongly dominates a model that restricts all coefficients to be equal. As stated above, a likelihood ratio test for the alternative that the two-group model dominates the 


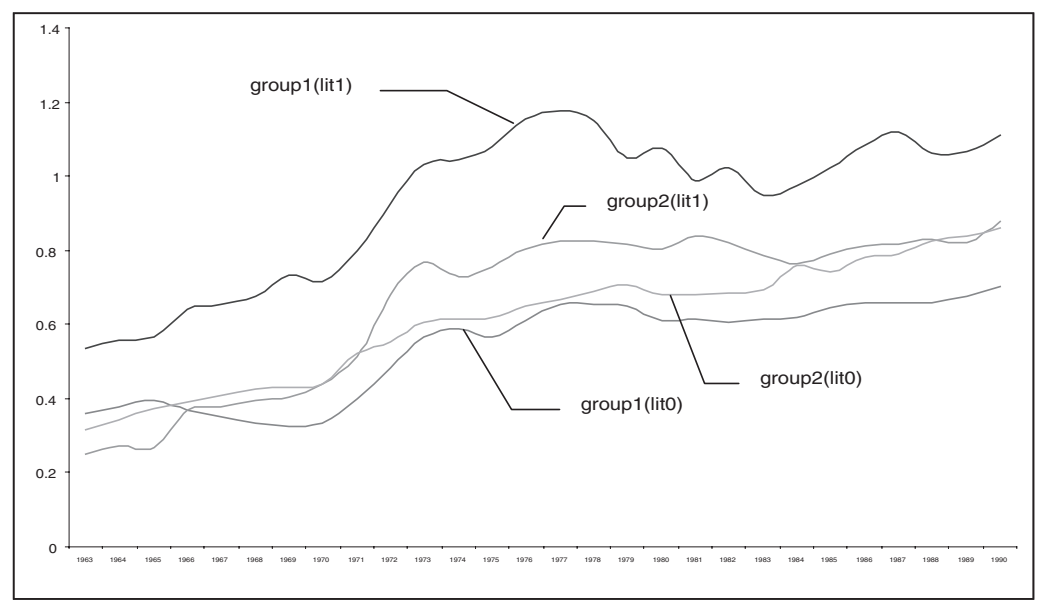

Figure 2: Prediction of Expenditures Based on Average (Year-by-Year Case) NOTE: $Y$-axis is real property tax per capita in $\$ 1,000$ s.

model with a single group is not well defined in a mixture model; see Wedel and Kamakura (1999) for details.

In general, the estimated coefficients on the other variables have the expected signs, and the magnitudes seem reasonable based on prior research. For example, the coefficients on real per capita income are positive across all four equations. The effect of a higher percentage of people below poverty is positive and significant in all cases, but the magnitudes of the coefficients are higher in the case of expenditures, which is unsurprising. For the property tax equations, the coefficient on the residential tax base (RESPROP), which is our measure of tax price, is negative and significant for group 2 , as expected, but is close to zero (and insignificant) for the other group of cities. The coefficients on RESPROP are negative and significant in both the expenditure equations.

We also estimated equations (8) and (9) combining all cities into one group. The coefficients on the local income and sales taxes are significant and indicated that the use of local taxes modestly increase expenditures and very modestly lower property tax revenues. However, the quantitative differences in the point estimates from the mix- 
ture model indicate that the restricted OLS coefficients mask the different underlying responses. To repeat, had we been able, a priori, to determine which cities belong to which groups, we could have obtained our results by interacting a dummy variable with all of the explanatory variables, where the dummy equals one if the city is in group 2. However, the lack of information on group membership required that we use the mixture model framework.

\section{SUMMARY AND CONCLUSIONS}

This article explores an alternative estimation strategy that allows the impacts of local taxes on property tax revenues and expenditures to differ across cities. The strategy does not require that we identify the factor or factors sorting the cities into different groups. The empirical results suggest that cities do in fact respond differently and that the differences are both substantive and statistically significant. One implication is that state cannot determine, a priori, whether cities will use a local sales or income tax to expand expenditures or reduce property taxes.

Although the estimation strategy presented here helps to solve some of the difficulties in modeling the behavior of local governments, a number of difficult issues remain. Probably the most important of these is how to account for the interrelated nature of tax revenues and government expenditures. Our model does not allow for correlation between the errors in the two equations, even though we believe the unobservable influences in the two equations to be related, if not identical.

The strong evidence that local governments respond differently to fiscal and economic conditions, in particular the existence of local sales and income taxes, suggests that empirical models could be improved through incorporating more flexibility in modeling state and local government behavior. In the case where prior knowledge exists on the sorting mechanism, or where there are theories to test regarding the sorting mechanism, a different estimation strategy would be pre- 


\section{ferred. However, as our results indicate, even with the lack of such prior information, useful empirical results can be obtained.}

\section{NOTES}

1. Local governments in Hawaii are authorized to levy a sales tax, but no local government currently exercises that authority. Although Alaska has no state sales tax, it does allow local sales taxes. States without local sales taxes are Connecticut, Delaware, Hawaii, Indiana, Kentucky, Maine, Maryland, Massachusetts, Michigan, Montana, New Hampshire, New Jersey, Oregon, Rhode Island, Vermont, and West Virginia (American Bar Association 2000).

2. Local governments in three states, Oregon, California, and New Jersey, utilize a payroll tax. Georgia and Arkansas authorize the use of the local income tax, but it is not currently used.

3. See also Munley and Greene (1978).

4. The analysis would not change if we assumed that public decisions are made by an elected official or a social planner.

5. The existence of fiscal illusion is subject to debate. For example, Oates (1988) suggested that there is little empirical support for it. Congleton (2001), however, presented a strong argument for its existence. See Mueller (2003) for a brief summary of the literature.

6. Logan (1986) developed a formal model under which voters can misperceive averages for marginal tax prices.

7. We estimated a number of regressions to determine a switch using population size, years of use of the local sales taxes, property tax "pressure" (estimated as the level of property tax in the absence of a local sales tax), and other characteristics. We did not find significant, consistent, and reasonable results from any of the regressions.

8. Some economic applications exist. See Geweke and Keane (1997) and Munkin and Trivedi (1999) for examples.

9. See Wedel (2002) for details on computing standard errors for mixture models.

10. In our sample, there are seventeen cities that receive sales tax revenue collected by the county through a regular sharing type of program. We code $L S T$ as zero in these cases as the tax is not the policy instrument of the city.

11. This variable is constructed using data from the Advisory Commission on Intergovernmental Relations (ACIR; 1995b).

12. To construct OPTAX, we took county property taxes and allocated them to the city on a per capita basis. The city school district taxes were added, or, if the school district extended beyond the city, they were allocated on a per capita basis.

13. We have assumed that $n \rightarrow \infty$, with $T$ fixed. The use of fixed effects would imply the number of parameters would also approach infinity. Unlike the usual ordinary least squares (OLS) fixed effects estimator, where the estimator of the unit effects is inconsistent, but the slope estimators remain consistent, here the model is nonlinear in the parameters and the incidental parameter problem indicates that the maximum likelihood estimator (MLE) of the slopes would also be inconsistent; see Lancaster (2000).

14. The equations were estimated using Glimmix.

15. For comparison purposes, we also estimated the two equations by OLS. These results indicate that the local sales and income taxes support increases in expenditures and reduce reliance 
on property taxes. These results are not robust to different model specifications such as fixed effects.

\section{REFERENCES}

Advisory Commission on Intergovernmental Relations (ACIR). 1988. Local revenue diversification: Local income taxes. Washington, DC: ACIR.

- 1995a. Changing public attitudes on government and taxes. Washington, DC: ACIR. - 1995b. Tax and expenditure limits on local governments. Washington, DC: ACIR.

. Various years. Significant features of fiscal federalism. Washington, DC: ACIR.

American Bar Association. 2000. Sales and use tax desk book: 1999-2000. Washington, DC: American Bar Association Section on Taxation.

Anderson, John E. 1995. City income tax adoptions. In Proceedings of the Eighty-Seventh Annual Conference on Taxation, 147-52. Columbus, $\mathrm{OH}$ : National Tax Association.

Atlanta Journal and Constitution. 1995. Gwinnett voices; Readers' letters; tell us what you think. Accessed via Lexis-Nexis on July 20, 2004.

Baker, Samuel H. 1983. The determinants of median voter tax liability: An empirical test of the fiscal illusion hypothesis. Public Finance Quarterly 11 (1): 95-108.

Bergstrom, Theodore C., and Robert P. Goodman. 1973. Private demand for public goods. American Economic Review 63 (3): 280-96.

Breeden, Charles H., and William J. Hunter. 1985. Tax revenue and tax structure. Public Finance Quarterly 13 (2): 216-24.

Borcherding, Thomas E., and Robert T. Deacon. 1972. The demand for the services of nonfederal governments. American Economic Review 62 (5): 891-906.

Buffalo News. 1993. Who would be winners, losers if we had a local income tax? Cuomo's idea to fund schools is too sketchy. Accessed via Lexis-Nexis on July 20, 2004.

Clotfelter, Charles T. 1976. Public spending for higher education: An empirical test of two hypotheses. Public Finances 31 (2): 177-95.

Congleton, Roger D. 2001. Rational ignorance, rational voter expectations, and public policy: A discrete informational foundation for fiscal illusion. Public Choice 107 (1-2): 35-64.

Craig, Eleanor D., and A. James Heins. 1980. The effect of tax elasticity on government spending. Public Choice 35 (3): 267-75.

Day, N. E. 1969. Estimating the components of a mixture of normal distributions. Biometrika 56 (3): $463-74$

Deran, Elizabeth. 1968. Tax structure in cities using the income tax. National Tax Journal $21: 147-52$.

DiLorenzo, Thomas J. 1982. Tax elasticity and the growth of local public expenditures. Public Finance Quarterly 10 (3): 385-92.

Dye, Richard F., and Therese J. McGuire. 1991. Growth and variability of state individual income and general sales taxes. National Tax Journal 44 (1): 55-60.

Feenberg, Daniel R., and Harvey S. Rosen. 1987. Tax structure and public sector growth. Journal of Public Economics 32 (2): 185-201.

Geweke, John, and Michael Keane. 1997. Mixture of normals probit models. Staff Report no. 237. Minneapolis, MN: Federal Reserve Bank of Minneapolis. 
Harmon, Oskar Ragnar, and Rajiv Mallick. 1994. The optimal state tax portfolio model: An extension. National Tax Journal 47 (2): 395-402.

Hettich, Walter, and Stanley L. Winer. 1999. Democratic choice and taxation: A theoretical and empirical analysis. New York: Cambridge University Press.

Houston Chronicle. 1994. A 6 percent property tax hike? Raise the local sales tax. Accessed via Lexis-Nexis on July 20, 2004.

Inman, Robert P. 1979. Subsidies, regulations, and the taxation of property in large U.S. cities. National Tax Journal 32 (3, June suppl.): 159-68.

. 1989. The local decision to tax: Evidence from large U.S. cities. Regional Science and Urban Economics 19 (3): 455-91.

Intelligencer Journal. 1998. Uniformed reform; property tax relief finally arrives but it's so weak it's not worth much. Accessed via Lexis-Nexis on July 20, 2004.

Ladd, Helen F., and Dana R. Weist. 1987. State and local tax systems: Balance among taxes vs. balance among policy goals. In The quest for balance in state-local revenue structures, ed. Frederick D. Stocker, 39-69. Tax Policy Roundtable, Property Tax Papers Series no. TRP-16. Cambridge, MA: Lincoln Institute of Land Policy.

Lancaster, Tony. 2000. The incidental parameter problem since 1948. Journal of Econometrics 95 (2): 391-413.

Logan, Robert R. 1986. Fiscal illusion and the grantor government. Journal of Political Economy 94 (6): 1304-18.

Merrifield, John. 2000. State government expenditure determinants and tax revenue determinants revised. Public Choice 102 (1-2): 25-50.

Misiolek, Walter S., and D. Grady Perdue. 1987. The portfolio approach to state and local tax structure. National Tax Journal 40 (1): 111-14.

Mueller, Dennis C. 2003. Public choice III. Cambridge: Cambridge University Press.

Mullins, Daniel, and Philip G. Joyce. 1996. Tax and expenditure limitations and state and local fiscal structure: An empirical assessment. Public Budgeting and Finance 15 (Spring): 75101.

Munkin, Murat, and Pravin K. Trivedi. 1999. Simulated maximum likelihood estimation of multivariate mixed-Poisson regression models, with applications. Econometrics Journal 2 (1): $29-48$.

Munley, Vincent G., and Kenneth V. Greene. 1978. Fiscal illusion, the nature of public goods and equation specification. Public Choice 33 (1): 95-100.

New York Times. 1997. A local income tax would shore up revenues. Accessed via Lexis-Nexis on July 20, 2004.

Oates, Wallace E. 1975. Automatic increases in tax revenue-The effect on the size of the public budget. In Financing the new federalism: Revenue sharing, conditional grants, and taxation, ed. Wallace E. Oates, 129-60. Baltimore: Johns Hopkins University Press.

. 1988. On the nature and measurement of fiscal illusion: A survey. In Taxation and fiscal federalism, ed. Geoffrey Brennen, Peter Groenewegen, and Bhajana S. Grewal. Sydney: Australian National University Press.

Omaha World-Herald. 1997. Local sales tax increase Ok'd in Fremont. Accessed via LexisNexis on July 20, 2004.

Pittsburgh Post-Gazette. 1994. A shift needed from real estate to income taxes. Accessed via Lexis-Nexis on July 20, 2004.

Ramaswamy, V., W. S. DeSarbo, D. J. Reibstein, and W. T. Robinson. 1992. An empirical pooling approach for estimating marketing mix elasticities with PIMS data. Marketing Science $12: 241-54$. 
St. Louis Post-Dispatch. 1997. Municipal league names panel to weigh revival of use tax. Accessed via Lexis-Nexis on July 20, 2004.

St. Petersburg Times. 1987. Local sales tax needed to handle county's growth. Accessed via Lexis-Nexis on July 20, 2004.

Stockfisch, J. A. 1985. Value added taxes and the size of government: Some evidence. National Tax Journal 38 (4): 542-47.

Suyderhoud, Jack P. 1994. State-local revenue diversification, balance, and fiscal performance. Public Finance Quarterly 22 (2): 168-94.

Times Leader. 2003. Pennsylvania districts to decide if income tax will replace property tax. Accessed via Lexis-Nexis on July 20, 2004.

Turnbull, Geoffrey K. 1992. Fiscal illusion, uncertainty, and the flypaper effect. Journal of Public Economics 48 (2): 207-23.

U.S. Bureau of the Census. Various years-a. Census of governments. Washington, DC: U.S. Census Bureau.

Various years-b. Census of the population. Washington, DC: U.S. Census Bureau

. Various years-c. City government finances. Washington, DC: U.S. Census Bureau.

Various years-d. County and city data book. Washington, DC: U.S. Census Bureau.

Wagner, Richard E. 1976. Revenue structure, fiscal illusion, and budgetary choice. Public Choice 25 (Spring): 45-61.

Wedel, Michel. 2002. Computing the standards errors of mixture model parameters with EM when classes are well separated. Working paper, University of Groningen, the Netherlands.

Wedel, Michel, and W. A. Kamakura. 1999. Market segmentation: Conceptual and methodological foundations. 2nd ed. Dordrecht, the Netherlands: Kluwer.

White, Fred C. 1983. Trade-off in growth and stability in state taxes. National Tax Journal 36 (1): $103-14$

David L. Sjoquist is a professor of economics, holder of the Dan E. Sweat Distinguished Scholar Chair in Educational and Community Policy, and a director in the Fiscal Research Center of the Andrew Young School of Policy Studies at Georgia State University.

Mary Beth Walker is an associate professor of economics and a senior associate in the Policy Research Center of the Andrew Young School of Policy Studies at Georgia State University. Her primary research interests lie in the areas of spatial econometrics and applications.

Sally Wallace is an associate professor of economics and associate director of the Fiscal Research Center of the Andrew Young School of Policy Studies at Georgia State University. Her main interests are domestic and international taxation and intergovernmental fiscal relations. From 1997 to 1999, she served as the chief of party of the Andrew Young Research School of Policy Studies Russia Fiscal Reform Project in the Russian Federation. 